\title{
A model of professionalism: Eugene Klatte, MD
}

\author{
Radya Osman $^{1} \cdot$ Richard B. Gunderman ${ }^{1}$
}

Received: 14 June 2020 / Revised: 14 June 2020 / Accepted: 13 August 2020 / Published online: 29 August 2020

(C) Springer-Verlag GmbH Germany, part of Springer Nature 2020

Students of pediatric radiology need to focus on many different learning objectives: the anatomy, physiology and pathology of the developing human; the roles of modalities such as radiography, ultrasound, CT and MRI in patient care; and the pediatric radiologist's collaborative relationship with multiple pediatric fields, such as general pediatrics, pediatric emergency medicine and pediatric surgery.

Yet some of the most formative lessons in the life of every pediatric radiologist are derived not from the curricula of radiology residency and fellowship programs, but the work and lives of senior colleagues who serve as the field's exemplars of excellence.

One such role model in the life of many pediatric radiologists - as well as radiologists in many fields of specialization - is Eugene Klatte, MD, who served for 30 years as chair of radiology at Vanderbilt University and Indiana University.

Born in Indiana, Klatte graduated from the Indiana University School of Medicine in 1952, completed his internship at the University of Michigan, his residency in radiology at the University of California San Francisco, and his fellowship as a Picker Scholar at Indiana University. He served as professor and chair of radiology at Vanderbilt from 1962 to 1971, professor and chair of radiology at Indiana University from 1971 to 1979 , and then distinguished professor and chair at Indiana from 1979 to 1991.

Klatte is also a founding member of both the Society for Pediatric Radiology and what is now the Society for Interventional Radiology. He received the gold medals of the Association of University Radiologists, the American Roentgen Ray Society, and the Radiological Society of North America. He also served as the president of the Society of Chairs of Academic Radiology Departments and served on the Board of Trustees of the American Board of

Richard B. Gunderman

rbgunder@iu.edu

1 Department of Radiology, Indiana University School of Medicine, 702 North Barnhill Drive, Room 1053, Indianapolis, IN 46202, USA
Radiology. But these lines on a curriculum vitae tell only part of the story.

The New York Times columnist David Brooks [1] distinguished between two types of virtues: resume virtues and eulogy virtues. Resume virtues consist of degrees earned, positions attained and awards garnered. Eulogy virtues, on the other hand, are the sorts of things people say about you at your funeral or memorial service. Brooks argued that eulogy virtues are the more important of the two, at least in the sense that they reveal a lot more about a person.

Why wait for a funeral to celebrate what Brooks calls a person's eulogy virtues? Discussing them in vivo provides timelier opportunities for others to learn from them. In addition, the discussion can provide the exemplar with a sense of satisfaction. In terms of four important eulogy virtues, Klatte serves as both a role model and an inspiration.

\section{Work ethic}

Like pediatric radiologists of his and every generation, Klatte achieved a well-earned reputation as a hard worker. After he retired and while in his 70s, Klatte returned to the full-time practice of pediatric radiology at Riley Hospital for Children in Indianapolis. Every day he worked, he was the first radiologist in the hospital, and for many years of his post-retirement service, he ranked as the most clinically productive of the radiologists in his section.

When seeking out radiologic consultation, Klatte's longtime colleagues in other specialties tended to seek him out, and more junior physicians also soon learned to do so. He also contributed as much to medical student and resident teaching as anyone in the pediatric radiology department and received multiple awards for educational excellence.

One of his colleagues said that Klatte never asked anyone else to do what he was unwilling to do himself. Despite his relatively advanced age, he insisted on working full-time and taking his full share of overnight and weekend call. An early 
riser, for several years he did the morning staffing of night float residents each day he worked.

Colleagues quickly discerned that he was doing all this work in large part because he enjoyed the practice of radiology. It provided opportunities to draw on a base of knowledge and experience that he had built up over many years and to keep learning a craft he loved. Colleagues realized that contributing to the care of infants, children and adolescents brought him to life.

\section{Lifelong learning}

Klatte is the epitome of a lifelong learner. When working, he was keen to share interesting cases with others and was the first to look over colleagues' good cases. He made more liberal use of the department library than any of his colleagues, poring over bound volumes of radiology journals in search of case reports, clinical series and research studies that spanned a time course of many decades.

Klatte kept a spiral bound notebook in the pocket of his white coat in which he would record good examples of different pathologies and notes for following up on the surgical and pathological findings in cases he saw. The temporary misplacement of one of these notebooks would result in a department-wide all-points bulletin.

Klatte embodied deep curiosity about radiologic findings and differential diagnoses and relished helping referring physicians solve diagnostic puzzles and clinical dilemmas. At the department's weekly "interesting case" conference, he invariably brought many cases to present.

Klatte was also the first person in the department to present cases that he had missed, and he did so with humility and a sincere desire to help his colleagues avoid similar mistakes. He did not always know the most about the latest MRI pulse sequences, but his deep knowledge of pathology and many years of experience enabled him to read MRI studies at least as well as the next person.

\section{Devotion to family}

One of the most remarkable things about Klatte is his devotion to family. He and his wife, Barbara, met at our children's hospital while he was a medical student and she was in nursing school. They married immediately after he graduated.

While Barbara was pregnant with their third of five daughters, she contracted polio and ended up dependent on an "iron lung" for a time. As the decades passed, her disability from post-polio syndrome increased to the point that she used a wheelchair and needed help with routine activities, including dressing and personal care.
Each day that Klatte arrived for a day's work in pediatric radiology, Barbara came with him. He would help her from the car to her wheelchair and into the hospital, where she would remain in his office throughout the day. At midday, the two would eat lunch together in his office, and at the end of the day, he would wheel her back out to the car and help her into her seat. Through this daily routine, he exemplified the importance of family.

Klatte also fostered a sense of family in the radiology department. He and his family would regularly host departmental gatherings that served as reunions for retired and departed colleagues. Everyone who worked in the department was invited, not just the radiologists, and even faculty and chairs of other departments attended. These and winter holiday gatherings became progressively more important as the department grew.

Klatte also established the custom of every-other-week catered department lunches at which radiologists could gather, discuss current challenges and opportunities, and build a sense of camaraderie and shared mission. In addition, he helped to establish departmental basketball and softball teams that often did well in intramural leagues.

\section{Professionalism}

Klatte is known as a person of integrity, and he expects the same from others. Some expressed surprise that he was so devoted to his wife for so many years, particularly as her health declined, but he always responded that he had married her for sickness and health.

Klatte regards her as his lifelong companion and friend, and his devotion shines through in the many photographs of the couple throughout the years. Despite her disability, they made many trips around the nation and to different parts of the world. He also saw to it that each of his children and grandchildren had the support they needed to pursue their educations as far as they wished.

If anyone in the department was unable to give a lecture, Klatte would step in and do it for them. He saw what others might regard as inconveniences or impositions as opportunities to serve. He seems to have approached each day not seeking to minimize the demands placed on him or conserve his time and energy, but rather to contribute as much as he possibly could.

In this respect, Klatte is both a role model and an inspiration to pediatric radiologists past, present and future. He knows a great deal, learns more every day, and possesses a fine set of technical skills, but what really distinguished Klatte in the practice of pediatric radiology was his dedicated care for patients and helping colleagues thrive. 


\section{Conclusion}

In educating pediatric radiologists, we need to look beyond knowledge and skill to the kinds of physicians and human beings we hope they will become. Here the best learning resources are not textbooks or journal articles, but real human beings - human beings such as Eugene Klatte. They set a high standard, but in striving to be worthy of their legacy, we stand the best chance of doing and being our best.

\section{Compliance with ethical standards}

Conflicts of interest None

\section{Reference}

1. Brooks D (2015) The road to character. Random House, New York

Publisher's note Springer Nature remains neutral with regard to jurisdictional claims in published maps and institutional affiliations. 